\title{
Geoffrey Edwin Rickman 1932-2010
}

Geoffrey Edwin Rickman died in February 2010, aged 77. A man of great wit and humour, he was also a remarkable scholar, an inspiring teacher, a wise administrator, and a great friend of the British School at Rome. ${ }^{1}$

In 2002, in his speech that represented his retirement as Chairman of the British School at Rome Council, and his 70th birthday, and the formal inauguration of the Sainsbury Lecture Theatre, Geoffrey Rickman declared 'I have been a very lucky man. I have loved two institutions and one woman in my life, and it has been my good fortune to have spent most of my life with all three - The University of St Andrews, the British School at Rome, and my wife Anna'.

Geoffrey came to the British School in 1958 with a Henry Francis Pelham Studentship from Oxford. It took him 36 hours by boat, train and bus, and like all of us, his first unnerving sight was Lutyens's magnificent façade atop the great stairs. Inside, was a unique world - John Ward-Perkins in the midst of one of Britain's truly great archaeological enterprises, the South Etruria Survey, his wife Margaret (described by Geoffrey as universal mother, aunt, nanny, nurse and hostess), scholars of future renown - in Geoffrey's year Peter Dronke, subsequently a great medieval Italian literature expert - and, unlike Oxford, artists and architects. 'A different non-verbal world of effort and achievement was opened up', Geoffrey wrote later in the School's centenary volume.

That was the year in which two photos of an astonishingly young and extraordinarily handsome looking Geoffrey were taken. One shows him improbably with a hula hoop on the front steps; the other, seated on a row of ancient lavatories at Ostia, and alongside him Martin Frederiksen, one of Britain's finest ancient historians, who died far too young, Derek Hill, whose beneficence to the artists of the School was remarkable and remains invaluable after his death, and Sir Anthony Blunt, then simply known as one of the world's great art historians. Geoffrey looks as if he is having a whale of a time, everyone is smiling broadly, and one would not be at all surprised if he had cracked a joke.

It was a memorable year, since it was also the year in which Geoffrey married Anna, and the School perhaps first heard the memorable words 'Oh Geoffrey',

1 This tribute is a compilation of addresses delivered by Prof. J.S. Richardson and Prof. C.J. Smith at a memorial service in St Andrews on 20 March 2010. 
as Anna sought to intervene as Geoffrey headed off in conversation towards potentially dangerous territory, although of course it was never really dangerous, because Geoffrey seemed not to have the capacity to offend.

They stayed on in Rome, according to Geoffrey because they had had such fun that he had forgotten to do what he said he was going to do, which was measure the buildings of Ostia. Geoffrey's engagement with Ostia was the beginning of an intellectual journey that lasted his whole life. Geoffrey published only two books - but what books. His work on Roman Granaries and Store Buildings (Cambridge, 1971) and on The Corn Supply of Ancient Rome (Oxford, 1980) were brave books confronting huge topics.

Understanding how Rome fed itself, and the consequences of the demands of the movement of food across a vast empire, was to shed light on critical social and economic processes. The labour involved in, and the bureaucracy attendant upon, the distribution and preservation of one of the fundamental staples of the ancient world was the kind of project that would now require teams of researchers and funding, but in braver days, individual scholars mastered their fields, and no-one ever doubted that Geoffrey was the master here. Both books were immediatcly standard, because of the breadth of reference. The corn supply in particular required knowledge of archaeology, ports, ships, demography, texts, inscriptions, papyri, often of the most boring kind, like receipts, but in Geoffrey's hands the whole came alive, and it helped one understand so much in Roman history. His achicvement was recognized by his election to the Fellowship of the British Academy in 1989.

Geoffrey was appointed to St Andrews in 1962. For many years, Geoffrey was Ancient History at St Andrews. (That is not to say that he began the department. The first lecturer in Ancient History was Peter Brunt, appointed to St Andrews in 1947 and later Camden Professor in Oxford, and he was followed by E.S. Stavely and Ursula Hall, both of whom made important contributions to the discipline.) Moreover, he collected around him a remarkable set of colleagues, some of whom remained in St Andrews in the flourishing and supportive milieu that he established, while others went on to be equally successful elsewhere. It is no disrespect to any of these, however, to say that Ancient History in St Andrews, and the estecm with which it is regarded in the world of classical scholarship across the globe, is Geoffrey's creation.

In fourteen years, Geoffrey increased the size of the teaching staff through the appointment of four lecturers. That increase, in a period that was not favourable to growth in universities, least of all in the study of the ancient world, was attributable almost entirely to Geoffrey's brilliance as a teacher. Geoffrey was able, through a combination of a passionate understanding of the ancient world, an engaging wit and a careful selection of slides (always including one with Anna alongside an ancient monument), to charm his students into an engagement with peoples and civilizations far distant from their own. In the preface of the volume of essays presented to him on his 65th birthday, entitled Modus Operandi, the editors wrote: 'For a whole generation of St Andrews students Geoffrey Rickman brought to his subject a unique style and glitter. A master of the spoken and of the written word, he taught that study of the ancient world was enormous fun as well as a rigorous scholarly enterprise that should address fundamental questions'. 


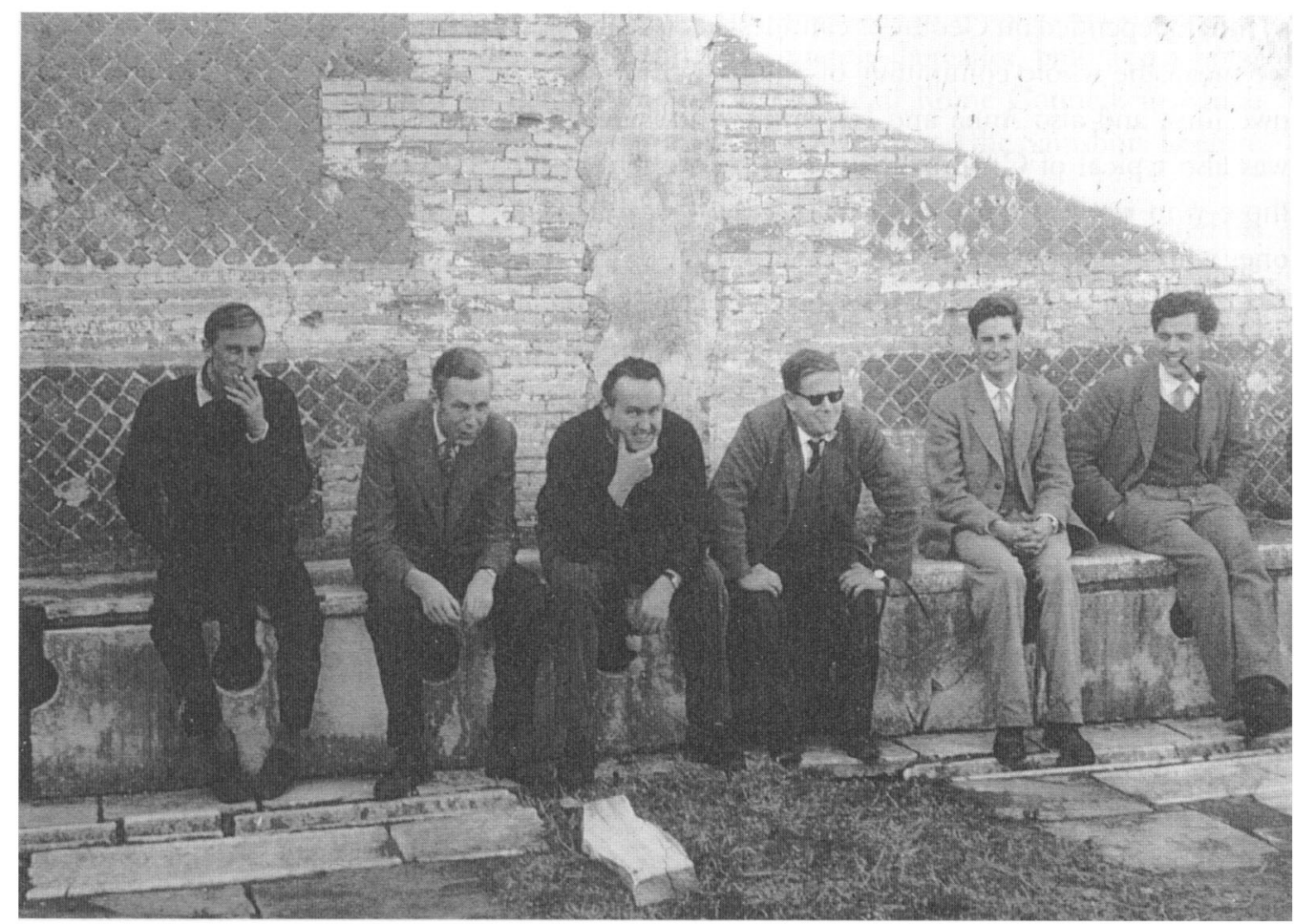

Geoffrey (second from right) at Ostia in 1958. His companions are (from left) Patrick Burke, Anthony Blunt, Derek Hill, Martin Frederiksen and Michael Ballance. (British School at Rome Archive, BS collection, no. 1119.)

He was immensely generous and concerned about the development of his younger colleagues; and hugely influential, both in St Andrews and in his engagements with students at the British School at Rome. As a historian, he was insistent on the significance of the actualities of life in the Roman world, on the Realien, the ways in which the ancients actually lived and worked, and Geoffrey was one of the firmest supporters of one of the School's most significant recent archaeological projects, the investigation of the site near Fiumicino simply known as Portus, the Port, and the network of ports connected to it. Geoffrey loved the Mediterranean, and he understood it in all its practicality.

When Geoffrey retired from St Andrews after a distinguished period as Master of the United College, the British School at Rome asked him to become chairman of its Council, and at a time of immense significance for us, for we were embarked on the most substantial building project since we opened on via Gramsci in 1916. A library extension, and a new lecture theatre, internal redevelopment and external improvement, utterly transformed the School. Professor Andrew Wallace-Hadrill has spoken often of how important Geoffrey's role was. He managed the immense pressures generated by a huge building project delivered with relatively small resources; he managed donors' demands, and panics, and reversals of directions, and all that naturally attends great adventures, without fuss, and with good humour. The result was a triumph, and 
so much depended on Geoffrey's calmness at critical times; the British School at Rome, by which we mean the whole community of scholars, artists and students who know and love the place, owe him, and also Anna and his family who were so supportive, an incalculable debt. Yet it was also typical of Geoffrey that when he thought of the School, he immediately thought of those who work in the kitchens, serve the food, mend the furniture - they after all are the ones who make it work.

Geoffrey was a man characterized by fascination and wonder, at the two improbable institutions he helped to transform, and at the world he loved to study. These were evergreen emotions - he never seemed to lose them. He was a rich and complex man, and an essential part of that complexity was a simple integrity. To quote again from the preface to his Festschrift in 1997, 'he was a connoisseur of life, a man who mastered the art of human relations to an uncommon degree'.

And knowing Geoffrey, he would be desperate to punctuate any solemnity with a drink, and an anecdote - perhaps the one about Geoffrey and the enormous trunk with which he arrived at the School, and which caused him endless mortification until he and the future head of the Income Tax eventually dragged it back to Termini station at the end of the year; or Geoffrey and his missing trousers in Wolfson College, Oxford; or Geoffrey and the wife of a terribly important man from the British Museum, who fainted when he tried to show her Ostia and one could of course go on and on; there will always be a memory of Geoffrey at the lunch table at the School in springtime, telling stories and making us all laugh.

Christopher Smith (British School at Rome) and JOHN RICHARDSON (University of Edinburgh) 


\section{The G.E. Rickman Memorial Fund}

Geoffrey Rickman was a lifelong supporter of the British School at Rome. He came to the School in 1958 as a Pelham Student, and returned frequently thereafter, both as a scholar and, from 1997 to 2002, as Chairman of the British School at Rome Council, in which invaluable role he steered the major redevelopment of the Library and the Sainsbury Lecture Theatre to completion.

Geoffrey had a particular interest in the School's work at Portus, which complemented his own research, and he was always passionately interested in the younger scholars who come through the School, many of whom have had a remarkable degree of success in gaining academic positions and distinction throughout the world.

In recognition of Geoffrey's contribution to the British School at Rome, and in his memory, we are launching a Memorial Fund with the specific intention of supporting existing scholars, establishing a Rickman Lecture, and funding our scholarship programme.

The British School at Rome currently makes awards for doctoral and post-doctoral students of all subjects within our mission 'to support scholarship in and on Italy from prehistory to the present day'. Award-holders gain enormously from the facilities we offer: a major international library, archive, contacts within Italy and across the other foreign academies in Rome, and a substantial lecture and conference programme.

We already target our financial support to award-holders without external funding, for whom the Britsh School at Rome award may be their only or main source of financial support. However, the financial support for these awards is relatively low, and this limits the awardees' capacity fully to exploit their time in Italy.

One goal of this Memorial Fund will be to support the community of award-holders at the School, to enable attendance at conferences and to foster other activities, such as workshops and research trips, that will develop the careers of the next generation of scholars.

We will also use some of the monies raised to fund an annual lecture related to the archaeology of the Mediterranean, and Geoffrey's own work and research in the archaeology or history of the Roman Mediterranean, particularly with port-related studies. We would seek to attract a scholar of international renown to the School to deliver a presentation, and to engage with the scholars at the School.

Ultimately, the critical goal must be to sustain our capacity to make awards, thereby enabling as many as possible to continue to benefit from researching at this wonderful institution that Geoffrey so loved. The British School at Rome remains the most important centre for research in Italy for British and Commonwealth students, and it is an urgent priority for us to restore the level of our scholarship activity to continue to fulfil that role.

In memory of Geoffrey Rickman, a true scholar and dedicated friend of the British School at Rome, I invite you to make as generous a donation as you can to enable us to continue his tradition of delighting in and developing opportunities for young scholars.

Christopher Smith

\section{Director, British School at Rome}

Cheques made payable to 'The British School at Rome' and identified as for the Rickman Memorial Fund should be sent to The British School at Rome, at The British Academy, 10 Carlton House Terrace, London, SW1Y 5AH, Great Britain; or please contact the Director (director@bsrome.it). 